Bangladesh J. Genet PI. Breed: 20(2): 51-57, 2007

\title{
GENOTYPIC AND PHENOTYPIC CORRELATION AND PATH ANALYSIS FOR LODGING RESISTANCE TRAITS IN BREAD WHEAT (Triticum aestivum L.)
}

\author{
Z. I. Sarker, A. K. M. Shamsuddin ${ }^{1}$, L. Rahman ${ }^{1}$ and R. Ara ${ }^{2}$ \\ Wheat Research Sub-Station \\ Bangladesh Agricultural Research Institute \\ Rajbari, Dinajpur, Bangladesh
}

\begin{abstract}
Relationships between the traits associated with lodging resistance in wheat were studied within the period of 1999-2002 at Wheat Research Center, Dinajpur in both $F_{1}$ and $F_{2}$ generations of a $9 \times 9$ diallel cross without reciprocal. The genotypic and phenotypic correlation coefficients studied in $F_{1}$ and $F_{2}$ generations were similar with some exceptions. In both $F_{1}$ and $F_{2}$ generation, the second internode breaking strength was positively correlated with diameter, wall thickness and unit-stem weight of second internode, and main shoot weight but negatively with plant height and second internode length at both genotypic and phenotypic levels. It was observed from path coefficient analysis in both $\mathrm{F}_{1}$ and $\mathrm{F}_{2}$ generations that the second internode unit-stem weight had high positive direct effect on it's breaking strength. Main shoot weight, second internode diameter and wall thickness positively influenced breaking strength through its unit-stem weight. Simultaneous selection for the traits contributing to lodging resistant in semi-dwarf wheat might be effective in the improvement of lodging resistance in bread wheat.
\end{abstract}

Key words: Wheat (T. aestivum L), lodging resistance, genotypic, phenotypic, correlation, path analysis,

\section{INTRODUCTION}

Lodging is a complex event, which is influenced by many morphological and anatomical plant traits such as culm length, basal internode length, culm diameter, wall thickness as well as breaking strength or elasticity of culm tissue, culm density, culm anatomy and chemical compositions of stem and root characters, head density and size etc. with some environmental factors. Lodging may occur in the lower two-three internodes of the plant. Pinthus (1973) observed that the lowest three or four internodal lengths have a greater effect on lodging. Stem lodging of wheat is greatly depends upon straw strength. Study of relationships between some important traits associated with lodging is very much important in choosing a suitable selection criterion for lodging resistance. The ideas about the association of lodging with some plant characters could be better explained through correlation coefficient study. Correlations among morpho-physiological characters are helpful in determining the components of complex traits like biomass, yield, lodging etc., but they did not provide an exact picture of the relative importance of direct and indirect influences of each of the component characters. The breeding strategies differ with the nature of association of these characters. Therefore, the relationships have been further analyzed by phenotypic and genotypic correlation coefficients. Then performed path coefficient analysis to disclose the cause and effects of chain relationships of different contributing characters with the most important character related to lodging resistance in bread wheat. The present investigation was undertaken to study the genotypic and phenotypic correlation and then path analysis for the traits associated with lodging resistance in bread wheat.

\footnotetext{
${ }^{1}$ Department of Genetics and Plant Breeding, Bangladesh Agricultural University, Mymensingh; ${ }^{2}$ Associate Professor, Department of Entomology, Hajee Mohammad Danesh Science \& Technology University, Dinajpur, Bangladesh
} 


\section{MATERIALS AND METHODS}

Nine spring wheat genotypes were crossed in a diallel mating system excluding the reciprocals in rabi 1999-2000. In the next rabi (2000-01), all 9 parents and their $36 \mathrm{~F}_{1} \mathrm{~s}$ and in following rabi (2001-02), all 9 parents and the $36 \mathrm{~F}_{2} \mathrm{~s}$ derived from their $36 \mathrm{~F}_{1} \mathrm{~s}$ were studied. In 200001 , the nine parents and their $36 \mathrm{~F}_{1} \mathrm{~s}$ were grown in the field in single row plot of 1.50 meter in length on November 24, 2000 placing seed $5 \mathrm{~cm}$ apart and row to row $25 \mathrm{~cm}$ at WRC farm, Dinajpur. In the next wheat-growing season, 2001-02, the nine parents and their $36 \mathrm{~F}_{2} \mathrm{~s}$ were grown in plots of $3.0 \mathrm{~m} \mathrm{x}$ $1.50 \mathrm{~m}$ having 6 rows (single row for each parent and 4 rows for each $\mathrm{F}_{2} \mathrm{~s}$ ) placing seed $10 \mathrm{~cm}$ apart and row-to-row $25 \mathrm{~cm}$ at WRC farm, Dinajpur. The seeds were sown on November 26, 2001. In both years, the experiments were sown in randomized complete block design with three replications. The crop was fertilized with NPKS @ 100, 28, 40 and $20 \mathrm{~kg} / \mathrm{ha}$, respectively (BARC, 1997). Two-thirds of the urea and the entire quantity of triple super phosphate, muriate of potash and gypsum were applied at final land preparation. The rest one-third urea was top dressed at 20 days after sowing following the first irrigation. Mulching and weeding was done at tillering stage 28-30 days after sowing. The second and third irrigations were given at booting stage and grain filling stage respectively. Relationships between some important traits closely associated with lodging resistance (five second internodal young stem traits with four post harvest traits) were studied at both genotypic and phenotypic levels in both $F_{1}$ and $F_{2}$ generations. The second internode breaking strength showed strong negative correlation with lodging score, it was considered as a criterion for lodging resistance (Sarker, 2003). Genotype and phenotypic correlation coefficients between characters contributing to lodging resistance as well as yield were estimated following the formula suggested by Miller et al. (1958). The cause and effect relationship between the most important lodging resistance attributer and its component characters, were separated into components of direct and indirect effects through path coefficient analysis. Path coefficient of the traits related to lodging resistance were analyzed from the phenotypic and genotypic correlations assuming the second internode breaking strength (as the substitute of lodging resistance) as the dependent variable following method of Singh and Chaudhary (1985) and Dabholkar (1992) which was originally developed by Wright (1921). Dewey and Lu (1959) employed this method for the first time in plants to disentangle the direct and indirect influences of component characters.

\section{RESULTS AND DISCUSSION}

\section{Genotypic and phenotypic correlations}

The genotypic and phenotypic correlation coefficients studied in $F_{1}$ and $F_{2}$ generations were similar in most of the cases with few exceptions (Table 1 and 2). In both $F_{1}$ and $F_{2}$ generations, the second internode breaking strength was positively correlated with main shoot weight, second internode diameter, second internode wall thickness and second internode unit-stem weight, but negatively correlated with second internode length at both genotypic and phenotypic levels. It had positive genotypic correlation with head/shoot ratio and negative genotypic correlation with spikes per plant. Second internode breaking strength was very closely and positively correlated with second internode unit-stem weight and second internode wall thickness at both genotypic and phenotypic levels. Similarly, second internode unit-stem weight was positively correlated with main shoot weight, second internode diameter and second internode wall thickness but negatively correlated with plant height and second internode length at both genotypic and phenotypic levels. It was very closely correlated with second internode diameter and second internode wall thickness at both genotypic and phenotypic levels. Main shoot weight was positively correlated with diameter, wall thickness and unit-stem weight of second internode at both genotypic and phenotypic levels but negatively correlated with spikes per plant only at genotypic level. Whereas, plant height was positively correlated with second internode length and spikes per plant but negatively correlated with head/shoot ratio, second internode wall thickness and second internode unit-stem weight at both genotypic and phenotypic levels. Similarly, second internode length was positively correlated with plant height and 
spikes per plant but negatively correlated with head/shoot ratio at both genotypic and phenotypic levels.

Table 1. Genotypic (above) and phenotypic (below) correlation coefficients between some plant characters related to lodging resistance in $F_{1}$ generation of bread wheat

\begin{tabular}{|c|c|c|c|c|c|c|c|c|}
\hline Characters & $\begin{array}{l}\text { Spikes } \\
\text { per } \\
\text { plant }\end{array}$ & $\begin{array}{c}\text { Main } \\
\text { shoot } \\
\text { weight }\end{array}$ & $\begin{array}{c}\text { Head } \\
\text { /shoot } \\
\text { Ratio }\end{array}$ & $\begin{array}{c}\text { Second } \\
\text { internode } \\
\text { length }\end{array}$ & $\begin{array}{c}\text { Second } \\
\text { internode } \\
\text { diameter }\end{array}$ & $\begin{array}{c}\text { Second } \\
\text { internode } \\
\text { wall } \\
\text { thickness }\end{array}$ & $\begin{array}{c}\text { Second } \\
\text { internode } \\
\text { unit-stem } \\
\text { weight }\end{array}$ & $\begin{array}{l}\text { Second } \\
\text { internode } \\
\text { breaking } \\
\text { strength }\end{array}$ \\
\hline $\begin{array}{l}\text { Plant height } \\
\text { Spikes per plant } \\
\text { Main shoot weight } \\
\text { Head /shoot ratio } \\
\text { Second internode } \\
\text { length } \\
\text { Second internode } \\
\text { diameter } \\
\text { Second internode } \\
\text { wall thickness } \\
\text { Second internode } \\
\text { unit-stem weight }\end{array}$ & $\begin{array}{l}0.580 * * \\
0.279 * *\end{array}$ & $\begin{array}{l}0.028 \\
0.083 \\
-0.241^{* *} \\
0.160\end{array}$ & $\begin{array}{l}-0.616 \text { ** } \\
-0.444 * * \\
-0.923 * * \\
-0.300 * * \\
-0.031 \\
-0.094\end{array}$ & $\begin{array}{l}0.798 * * \\
0.719 * * \\
0.702 * * \\
0.283 * * \\
-0.118 \\
-0.079 \\
-0.708 * * \\
-0.386 * *\end{array}$ & $\begin{array}{l}-0.279 * * \\
-0.207 * \\
-0.027 \\
0.027 \\
0.580^{* *} \\
0.366^{* *} \\
-0.294 * * \\
-0.119 \\
-0.185^{*} \\
-0.109\end{array}$ & $\begin{array}{c}-0.448 * * \\
-0.394 * * \\
-0.650 * * \\
-0.195 * \\
0.709 * * \\
0.488 * * \\
0.331 * * \\
0.169 * \\
-0.587 * * \\
-0.497 * * \\
0.568 * * \\
0.492 * *\end{array}$ & $\begin{array}{l}-0.377 * * \\
-0.334 * * \\
-0.420 * * \\
-0.112 \\
0.719 * * \\
0.474 * * \\
0.094 \\
0.071 \\
-0.556 * * \\
-0.464 * * \\
0.833 * * \\
0.546 * * \\
0.815 * * \\
0.622 * *\end{array}$ & $\begin{array}{l}-0.266 * * \\
-0.262 * * \\
-0.413^{* *} \\
-0.074 \\
0.641^{* *} \\
0.433^{* *} \\
0.206^{*} \\
0.116 \\
-0.595^{* *} \\
-0.524 * * \\
0.556^{* *} \\
0.428^{* *} \\
0.835^{* *} \\
0.728^{* *} \\
0.949 * * \\
0.815^{* *}\end{array}$ \\
\hline
\end{tabular}

The phenotypic correlation of spikes per plant with main shoot weight, second internode unit-stem weight and second breaking strength were improved in $F_{2}$ from $F_{1}$ generation. Similarly the genotypic correlations of plant height with main shoot weight, spikes per plant with second internode diameter were improved in $\mathrm{F}_{2}$ from $\mathrm{F}_{1}$ generation. The genotypic and phenotypic correlations of main shoot weight with head/shoot ratio and second internode length, and phenotypic correlation plant height with second breaking strength changed in $\mathrm{F}_{2}$ from $\mathrm{F}_{1}$ generation. The genotypic correlation of second internode diameter with head/shoot ratio and second internode length changed in $F_{2}$ from $F_{1}$ generation. The differences of growing environments (as the two generations were grown in different years) and the differences in genetic composition of the populations in $\mathrm{F}_{1}$ and $\mathrm{F}_{2}$ might be responsible for the dissimilarities in the estimates of genotypic and phenotypic correlations between $F_{1}$ and $F_{2}$ generations.

Table 2. Genotypic (above) and phenotypic (below) correlation coefficient between some plant characters related to lodging resistance in $F_{2}$ generation of bread wheat

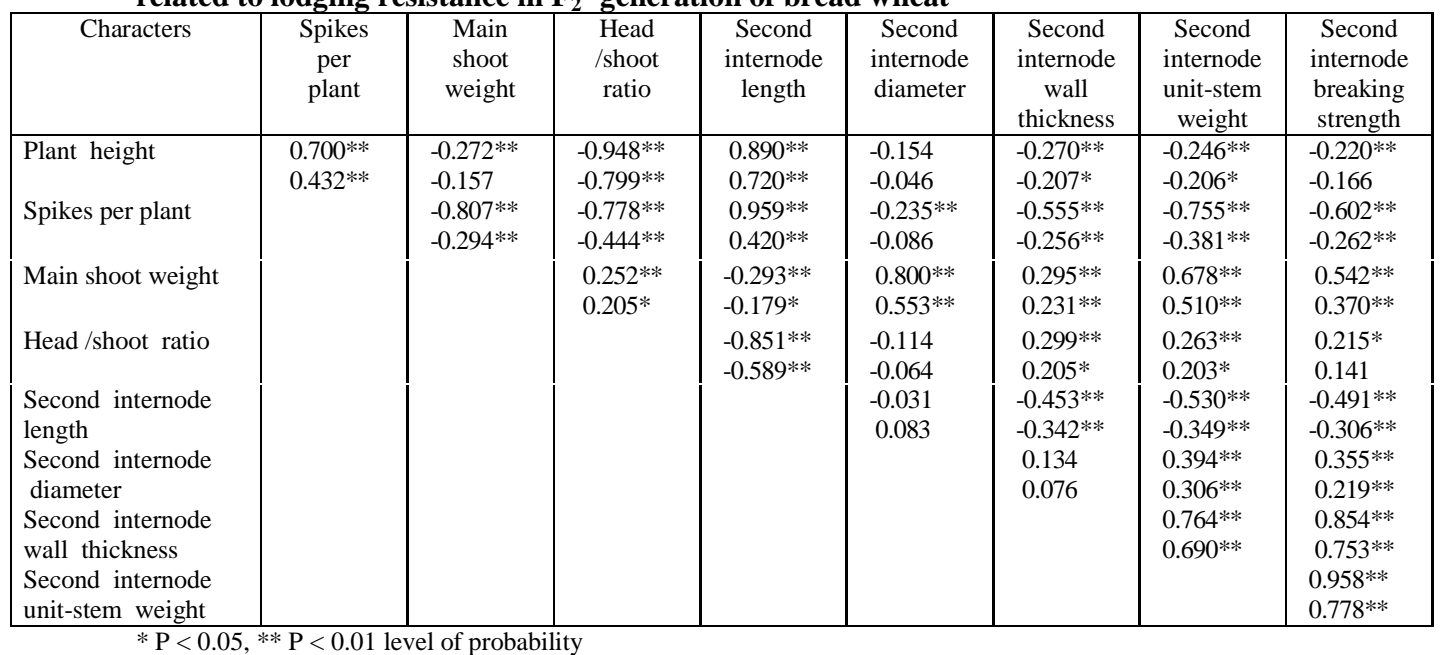


It was observed that there were more number of significant genotypic correlations with higher magnitude than and phenotypic correlations in both generations. Sometimes, the correlations between traits were non-significant at phenotypic level but found significant at genotypic level in both generations. In most of the cases the genotypic correlations were higher than their corresponding phenotypic values. The higher estimates of genotypic correlation than phenotypic correlation has been reported by Jatasra and Paroda (1978), Nanda et al. (1980), Razzaque et al. (1981) and Deswall et al. (1996). It indicated that there were fairly strong inherent relationships between the characters but the relationships were suppressed by the environmental influence at phenotypic level. Such environmental influence in reducing correlation coefficients was also reported by Agrawal et al. (1977) and Joshi et al. (1982). The genotypic correlation accounted for only additive genetic effects whereas phenotypic correlation for both additive and non-additive genetic effects. The differences in nature of correlation coefficient between phenotypic and genotypic levels suggested that either environmental or non-additive genetic effects or interaction or both influenced these associations of characters. Sidwell et al. (1976) also observed environmental influences on correlations in winter wheat. Tandon et al. (1973) observed that plant height was significantly and positively correlated with second internode length and negatively with culm weight per unit length in barley. Internode length was negatively associated with culm weight per unit length and culm wall thickness and the latter two were related to one another positively. High genotypic correlation coefficient between two characters does not always indicate the presence of linkage between them. Two characters having a common physiological or biochemical chain may also show such genotypic correlation (Hohenboker, 1985). This is particularly true for complex characters like yield, biomass, straw breaking strength etc. which are determined by some component characters. Relationship of these characters with their components can be explained as physiological and developmental. The high negative genotypic and phenotypic correlations between plant height and internode length with internode breaking strength in both generations in the present materials suggesting selection for strong strawed and dwarf genotypes for lodging resistance in bread wheat.

\section{Path coefficients analysis}

The cause and effect relationship between a dependent trait and its component traits was separated into components of direct and indirect effects through path coefficient analysis. Path coefficients of the traits related to lodging resistance was analyzed from the genotypic correlations in both $\mathrm{F}_{1}$ and $\mathrm{F}_{2}$ generation considering second internode breaking strength (the trait closely associated with stem lodging resistance) as dependent character.

Table 3. Genotypic path coefficient of some important plant characters related to lodging resistance on the second internode breaking strength in $F_{1}$ generation

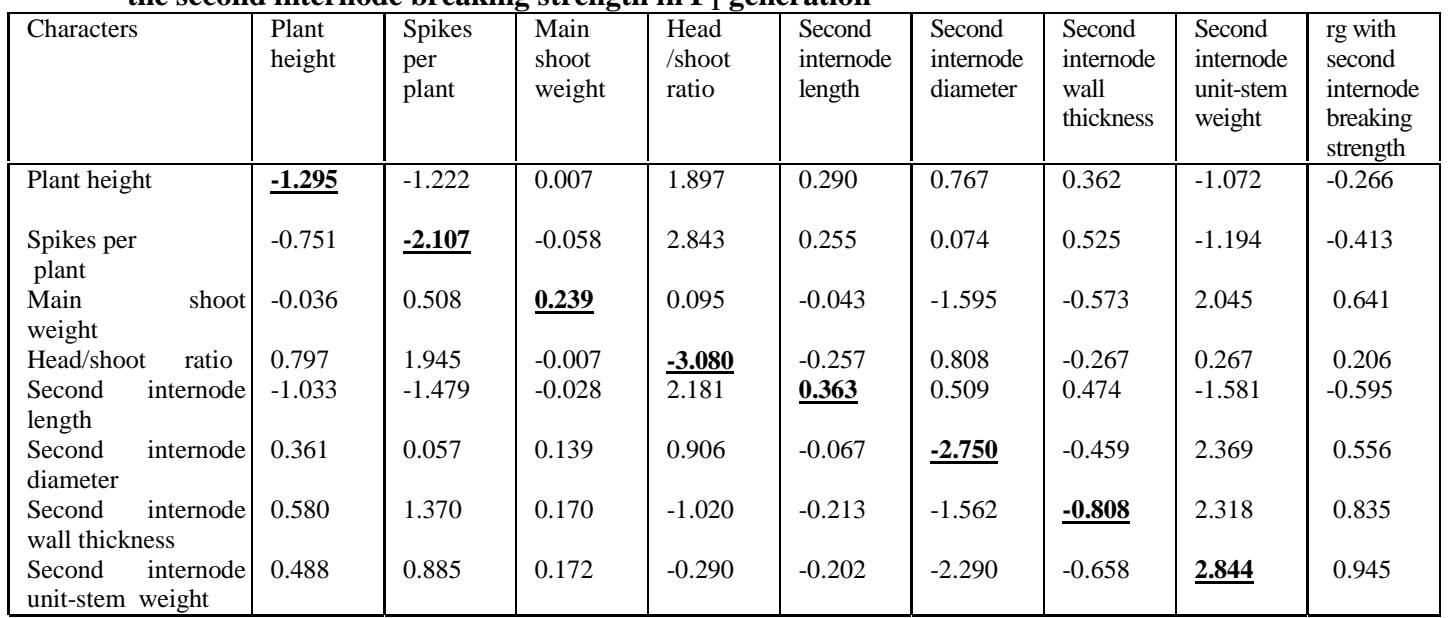

Residual effect $= \pm 0.115$; The values (bold and underlined) in diagonals are direct effects and off-diagonals are indirect effects. 
In $\mathrm{F}_{1}$ generation, the second internode unit-stem weight had very high positive direct effect on second internode breaking strength and suggested that this character contributed directly to the trait closely associated with stem lodging resistance. Main shoot weight, second internode diameter and second internode wall thickness influenced breaking strength indirectly in positive direction through second internode unit-stem weight (Table 3). Plant height, spikes per plant and head/shoot ratio contributed to second internode breaking strength considerably but in negative direction. This suggested that tall plant with more heads and more head weight would be liable to lodging. Interestingly second internode diameter showed negative and high direct effect on its breaking strength but the character had positive correlation with the breaking strength. This was due to its positive and high indirect effects of it through second internode unit-stem weight to internode breaking strength.

In $F_{2}$ generation, the second internode unit-stem weight had high positive direct effect on second internode breaking strength which was almost equal to the correlation coefficient between them, expressing true relationship and suggested that this character contributed directly to second internode breaking strength. Main shoot weight and second internode wall thickness along with second internode diameter influenced breaking strength indirectly in positive direction through second internode unit-stem weight (Table 4) as observed in $F_{1}$ generation. Spikes per plant and second internode length contributed to second internode breaking strength considerably but in negative direction.

Table 4. Genotypic path coefficient of some important plant characters related to lodging resistance on second internode breaking strength in $F_{2}$ generation

\begin{tabular}{|c|c|c|c|c|c|c|c|c|c|}
\hline Characters & $\begin{array}{l}\text { Plant } \\
\text { height }\end{array}$ & $\begin{array}{l}\text { Spikes } \\
\text { per } \\
\text { plant }\end{array}$ & $\begin{array}{c}\text { Main } \\
\text { shoot } \\
\text { weight }\end{array}$ & $\begin{array}{c}\text { Head } \\
\text { /shoot } \\
\text { ratio }\end{array}$ & $\begin{array}{l}\text { Second } \\
\text { internode } \\
\text { length }\end{array}$ & $\begin{array}{l}\text { Second } \\
\text { internode } \\
\text { diameter }\end{array}$ & $\begin{array}{l}\text { Second } \\
\text { internode } \\
\text { wall } \\
\text { thickness }\end{array}$ & $\begin{array}{c}\text { Second } \\
\text { internode } \\
\text { unit-stem } \\
\text { weight }\end{array}$ & $\begin{array}{c}\text { rg with } \\
\text { second } \\
\text { internode } \\
\text { breaking } \\
\text { strength }\end{array}$ \\
\hline Plant height & $-\underline{0.266}$ & 0.013 & 0.061 & 0.130 & 0.154 & -0.010 & -0.053 & -0.248 & -0.220 \\
\hline $\begin{array}{l}\text { Spikes per } \\
\text { plant }\end{array}$ & -0.186 & $\underline{0.018}$ & 0.180 & 0.107 & 0.166 & -0.015 & -0.110 & -0.763 & -0.602 \\
\hline Head/shoot ratio & 0.252 & -0.014 & -0.056 & $-\underline{0.137}$ & -0.147 & -0.007 & 0.059 & 0.266 & 0.215 \\
\hline $\begin{array}{l}\text { Second internode } \\
\text { length }\end{array}$ & -0.237 & 0.017 & 0.066 & $\overline{0.117}$ & $\underline{0.173}$ & -0.002 & -0.089 & -0.535 & -0.491 \\
\hline $\begin{array}{l}\text { Second internode } \\
\text { diameter }\end{array}$ & 0.041 & -0.004 & -0.179 & 0.016 & -0.005 & $\underline{0.063}$ & 0.026 & 0.398 & 0.355 \\
\hline
\end{tabular}

The values (bold and underlined) in diagonals are direct effects and off-diagonals are indirect effects

Residual effect $= \pm 0.172$

Tandon et al. (1973) studied the relationship between lodging resistance and five morphological characters in sixty-two cultivars of barley. The path coefficient analysis revealed that plant height and culm wall thickness were the only components making direct contribution to lodging score. Culm weight per unit length had indirect negative effect towards lodging resistance via plant height and culm wall thickness. While the second internode length exerted its influence via plant height. Culm diameter made negligible contribution towards lodging. Path analysis by Wang-Yong (1995) showed that stem strength was closely related to cultivar lodging resistance.

From the present study of relationships between lodging resistance and its associated characters through simple, genotypic and phenotypic correlations, it is evident that internode breaking strength particularly the second internode was the most important character for determining stem 
lodging resistance. The second internode breaking strength was directly dependent on its unit-stem weight, wall thickness and diameter. Plant height, spikes per plant and head/shoot ratio contributed to the second internode breaking strength considerably but in negative direction. This suggested that the tall plant with more numbers of heads and more head weight would be liable to lodging. This indicated that selection for internode unit-stem weight, wall thickness and diameter would give better response in internode breaking strength as well as for stem lodging in the present material. The correlation and path analysis suggested that a single plant character related to straw strength as well as to lodging would not be a reliable or satisfactory method of assessing lodging resistance. Simultaneous selection for the aforesaid traits closely related with lodging in semidwarf or in double dwarf genotypes at early generation might be effective in the improvement of lodging resistance in bread wheat.

\section{REFERENCES}

Agrawal, R. K., R, Sharma, G. S. Sharma, R. B. Singh and R. Nandan. 1977. Variability and associations of coleoptile length and other traits in wheat. Indian J. Agric. Sci. 47 : 234236.

BARC. 1997. Fertilizer Recommendation Guide. Published by Bangladesh Agril. Res. Council, Dhaka, Bangladesh. p 44.

Dabholkar, A. R. 1992. Elements of Biometrical Genetics. Concept Pub. Co. New Delhi, India.

Deswall, R. K., S. S. Grakh and K. K. Berwal. 1996. Genetic variability and characters association between grain yield and its components in wheat. Annals of Biol. Ludhiana. 12:221-224.

Dewey, D. R. and K. H. Lu. 1959. A correlation and path coefficient analysis of components of crested wheat-grass seed production. Agron. J. $51: 515-518$.

Hohenboken, W. D. 1985. Phenotypic, genetic and environmental correlations. In general and quantitative genetics. ed. A. B. Chapman. Elsevier Science Publishers B. V. Amstardam. pp. 121-134.

Jatasra, D. S. and R. S. Paroda. 1978. Characters association in three generations of wheat under different environmental conditions. Cereal Res. Common. $6: 83-94$.

Joshi, A.K., G.S. Sharma and R. Dhari. 1982. Vairability and associations of flag leaf area and other traits in wheat. Indian J. Agric. Sci. 52: 351-355.

Miller, P. A., J. C. Williums, H. F. Robinson and R. F. Comstock. 1958. Estimates of genotypic and environmental variances and covariances in upland cotton and their implication in selection. Agron. J. $50:$ 126-131.

Nanda, G. S., G. N. Hazarika and K. S. Gill. 1980. Association analysis in wheat. Sci. Cult. 46: 200202.

Pinthus, M. J. 1973. Lodging in wheat, barley, and oats : The phenomenon, its causes, and preventive measures. Advances in Agron. $25: 209-263$.

Razzaque, C. A., M. Rahman, A. K. Patwary and M. S. Rahman. 1981. Correlation and path analysis for yield and yield components, days to flowering, grain filling and maturity period in bread wheat. Bangladesh J. Bot. $10: 100-107$.

Sarker, Z. I. 2003. Inheritance of lodging resistance related to dwarfing gene effects in bread wheat. Ph.D. Thesis, Dept. of Genet. and Plant Breed., BAU, Mymensingh, Bangladesh.

Sidwell, R. J., E. L. Smith and R. W. McNew. 1976. Inheritance and interrelationships for grain yield and selected yield-related traits in a hard red winter wheat cross. Crop Sci. $16: 650-654$.

Singh, R. K. and B. D. Chaudhary. 1985. Biometrical methods in quantitative genetic analysis. pp. 79-85. Kalyani Publishers, N. D. India.

Tandon, J. P., K. B. L. Jain and S. B. Singh. 1973. Relationship between lodging resistance and some morphological characters in barley. Indian J. Genet. $33: 347-353$.

Wang Yong, Li QiugQi, Y. Wang and Q. Q. Li. 1995. Evaluation method of stem lodging resistance in wheat. Acta Agriculturae Boreali Sinica. $10: 84-88$.

Wright, S. 1921. Correlation and causation. J. Agric. Res. 20 : 557-585. 